\title{
Employment intensity and sectoral output growth: a comparative analysis of Egyptian and Jordanian economies ${ }^{1}$
}

\author{
Chahir Zaki ${ }^{*}{ }^{* *}$, Nooh Alshyab***, Nesreen Seleem*
}

\author{
DOI: $10.30682 / \mathrm{nm} 2001 \mathrm{c}$
}

JEL codes: J23, E24, C33

\begin{abstract}
The purpose of this article is to assess the relationship between employment intensity and sectoral output growth, to examine whether economic growth was jobless or has created more jobs. Using panel data for 10 sectors over the period 1983-2010 for two Middle Eastern countries; Egypt and Jordan, we estimate employment-value added elasticities at the sectoral level using a random coefficient estimation technique. Our main findings show that while manufacturing is the most important sector that creates jobs in Egypt, services are more important in Jordan. For both countries, the mining sector is insignificant. Indeed, this shows to what extent this sector is capital intensive, does not have a significant value-added and thus does not create jobs. A more detailed look at the decomposition analysis shows that the contribution of employment growth to value-added was higher than that of labor productivity. For Jordan, its growth was mainly attributed to employment growth while its productivity growth was negative.
\end{abstract}

Keywords: Employment intensity, jobless growth, sectoral output, Egypt, Jordan.

\section{Introduction}

Economic growth should foster employment. Indeed, the higher the growth level, the larger the number of investments that will be undertaken leading to a higher level of employment. This in turn should raise economic growth. The link between growth and labor markets has been underlined by the global financial crisis where different countries experienced a "jobless recovery". The latter term shows how output recov- ered relatively quickly in the wake of the global financial crisis, but unemployment did not (Salvatore, 2018; Impiglia and Lewis, 2019). Therefore, while some economists have highlighted the importance of using fiscal policy to address the problem of unemployment, others proposed that policy makers should focus on monetary policy as the financial crisis reduced dramatically credit flows to the real economy. A third group argued that only structural policies, as contrasted to stabilization policies, can affect employment

\footnotetext{
${ }^{1}$ We are grateful to Mohamed Goaied (Qatar University) who helped us in a previous version of this paper. We are also grateful to Nabil Boubrahimi (Ibn Tofail University), Suhail Maghableh (Yarmouk University) and Marouane Raissi (Ibn Tofail University). This work was funded by the Euro-Mediterranean Network of Economics Studies (EMNES).

${ }^{*}$ Cairo University, Giza, Egypt.

${ }^{* *}$ Economic Research Forum (ERF), Giza, Egypt.

*** Yarmouk University, Irbid, Jordan.

Corresponding author: chahir.zaki@feps.edu.eg
} 
and hence lead to a structural change. Thus, developing economies should focus on the manufacturing sector that creates jobs and that has a high value added compared to agriculture and services.

While the literature on this topic is rather abundant, few studies are applied on the Middle East and North Africa region. Furthermore, most of the studies were undertaken at the macroeconomic level. Hence, the purpose of this article is to assess the relationship between employment intensity and sectoral output growth, to examine whether economic growth was jobless or has created more jobs. Its contribution is three-fold. First, we provide a comparative analysis for two the Middle East countries; Egypt and Jordan. Second, we take into consideration sectoral heterogeneity to see which sector is more likely to generate jobs. Third, we decompose value-added growth into two components employment growth and productivity growth. Hence, using panel data for 10 sectors over the period $1983-2010^{2}$ for the two countries, we estimate employment-value added elasticities at the sectoral level using a random coefficient estimation technique. From a policy perspective, this empirical exercise is important as it helps identify which sectors are more likely to generate jobs and hence reducing unemployment in these countries, being characterized by a high level of youth unemployment.

Our main findings show that while manufacturing is the most important sector in term of job creation in Egypt, services are more important in Jordan. For both countries, the mining sector is insignificant. Indeed, this shows to what extent this sector is capital intensive, does not have a significant value-added and thus does not create jobs. A more detailed look at the decomposition analysis shows that the contribution of employment growth to value-added was higher than that of labor productivity. Jordan's growth was mainly attributed to growth in employment while its productivity growth was negative. In fact, in Jordan, the services sector employs the vast majority of the workforce. Hereby, despite a significant downsizing in the frame of the economic reform process, public administration, defense, and social services remain a highly employment intensive sector, followed by trade. Trade also registered the most sustained average employment growth over the considered period.

The paper is organized as follows. The conceptual framework is presented in Section 2 with a brief review of the theoretical literature. Section 3 presents a general overview of the region. Section 4 shows the main labor reforms that took place in the two countries. Section 5 is dedicated to the methodology and data. Section 6 shows the empirical findings and Section 7 concludes.

\section{Conceptual framework}

For a long period of time, economists have regarded economic growth and labor economics as two disconnected fields of study dealing with different issues. Standard long-run growth theories, on one hand, have generally dealt with the full-employment state of the economy predicting that the economy's growth rate is independent of the rate of unemployment. Labor economics theories, on the other hand, have generally assumed a static state with regard to the economy's productive capacity with no account for growth in the unemployment models (Adachi, 2007; Arico, 2003).

Yet, Arthur Okun was one of the first economists to consider a theoretical integration between economic growth and unemployment. His economic model - known as "Okun's Law" - was based on the study of the United States' economy (Podgórska and Leśniowska-Gontarz, 2016). The law describes the relationship between deviations of real output and unemployment from their long-run equilibrium trends, usually referred to as potential output and the natural rate of unemployment, respectively (Freeman, 2001).

The key to the long-run relationship between output growth and unemployment is the growth

\footnotetext{
2 Since sectoral data were not available for the two countries after 2010, we limit our analysis to the period 1980 2010 for the two countries in both the empirical and the descriptive parts.
} 
rate of potential output. ${ }^{3}$ The rate of growth of potential output, on the other hand, is a function of the growth rates of potential labor productivity and the labor force when the economy is performing at the full employment level. In light of this framework, Okun's Law states that as long as the growth rate of GDP exceeds the combined growth rates of labor productivity and labor force (i.e. the growth rate of potential output), the unemployment rate decline will in the long run $^{4}$ (Levine, 2012). This negative relationship between economic growth and the rate of unemployment is one of the most consistent relationships in macroeconomics (Adachi, 2007). Hence, Okun's Law can be formally expressed as follows:

$$
U-U^{*}=\beta\left(\frac{Y-Y^{*}}{Y^{*}}\right)
$$

Where; $U$ is the unemployment rate, $Y$ is the real GDP, and $\beta$ is the Okun's coefficient. An asterisk denotes the natural rate or the potential levels of the variables (Podgórska and Leśniowska-Gontarz, 2016; Dumitrescu et al., 2009). Equation (1) states that for each percentage point by which the actual rate of unemployment falls below the natural rate, real GDP is $\beta \%$ above its potential level (Dumitrescu et al., 2009).

In his original paper in 1962, Okun empirically demonstrated that every one percentage point reduction in the unemployment rate in the United States was associated with an output growth of three percentage points above the potential output. The coefficient, however, can differ among countries and over time (Adachi, 2007). More recent estimates of this relationship in the United States find that in order to reduce unemployment by one percentage point during a year, the growth rate of GDP must surpass that of potential output by approximately two percentage points over the same period (Levine, 2012).

This inverse relationship was reinforced by Pissarides in his seminal work "Equilibrium Un- employment Theory" in 1990. By combining a conventional matching model with technological change (i.e. economic growth), Pissarides developed a theoretical framework to study the labor market in a dynamic setting; concluding a negative relation between growth and unemployment due to the capitalization effect of economic growth on unemployment. According to this model, a higher growth (higher productivity growth) increases firms' rate of return from job creation which in turn induces firms to create more jobs today in order to save in future hiring costs and also encourages new firm to enter into the market leading to an increase in the job openings and a reduction in long-run unemployment rate (Neto and Silva, 2013; Liu and Zeng, 2008; Arico, 2003).

Aghion and Howitt (1994), on the other hand, suggests that economic growth and unemployment are not necessarily positively related. In their paper, they identified two competing effects of economic growth on unemployment. The first is the capitalization effect; in which an increase in the economy's growth rate raises the firms' returns from creating jobs and consequently reduces unemployment by increasing the job-finding rate. This effect, as in Pissarides, suggests an inverse relation between growth and unemployment. The second effect is the creative destruction effect; which on the other hand, suggests a positive relation between the two variables. In this model, long-run growth is driven by the introduction of new technologies. These industrial innovations are usually accompanied by automation and fast obsolescence of skills which shortens the duration of job match. This in turn raises the rate of unemployment directly by raising the job separation rate and indirectly by discouraging firms from creating job openings thereby reducing the job-finding rate (Liu and Zeng, 2008; Aghion and Howitt, 1994). Given the interplay between these two competing effects, the authors suggest that unemployment can be viewed as an inverted U-shaped function

\footnotetext{
${ }^{3}$ Potential output measures the economy's productive capacity when the available resources are fully utilized (Levine, 2012).

${ }^{4}$ Employment will rise whenever the growth in GDP exceeds the growth in labor productivity, and if employment grows faster than the growth in labor force, then unemployment rate will decline (Levine 2012).
} 
of the growth rate; where the relation between unemployment and economic growth is positive at low rates of growth and then turns negative as the growth rates becomes higher (Liu and Zeng, 2008; Arico, 2003).

In a nutshell, while the literature on growth and employment and/or unemployment is inconclusive, we try to provide an empirical assessment of this relationship at the sectoral level for two emerging economies in the MENA region, namely Egypt and Jordan.

\section{General overview}

The GDP structure shows some similarities among the Southern Mediterranean countries. All countries are services-based economies, which account for $48-66 \%$ of GDP in 2010. Jordan surpassed Tunisia and Morocco, which has initially the highest share of service sector. The contribution of agriculture to GDP has declined for all countries during the period 1980-2010 but has remained important except for Jordan where it represents $3 \%$ of GDP. ${ }^{5}$

We note disparities in the sectoral employment structure among the Southern Mediterrane- an countries: services activities are the primary employer in these countries except for Morocco where the share of agricultural workers is almost $40 \%$, followed by $22 \%$ industrial workers. Jordan has the largest services sector, which employs $80 \%$ of workers, while employment in agriculture does not exceed $2 \%$ of total workforce.

Regarding our two economies of interest, in the Sixties, Egypt adopted a central planning system in which the state dominated most aspects of the economy while the contribution of the private sector in economic activity was fairly low (Dobronogov and Iqbal, 2005). Despite initial success, the system reached its limits by the end of the decade and could not sustain the high levels of economic growth; with annual GDP growth rates declining from a peak of $6.8 \%$ in 1969 to an annual average of $2.9 \%$ between 1970 and 1973 (Bolbol et al., 2005). Despite the declining levels of economic growth, unemployment was negligible - below $2.5 \%$ annually - throughout this period, as the state played a central role in job creation through large investments in infrastructure, agriculture, and import substitution industries. The government also followed an employment guarantee policy in which

Figure 1 - Sectoral value added (percentage of GDP).

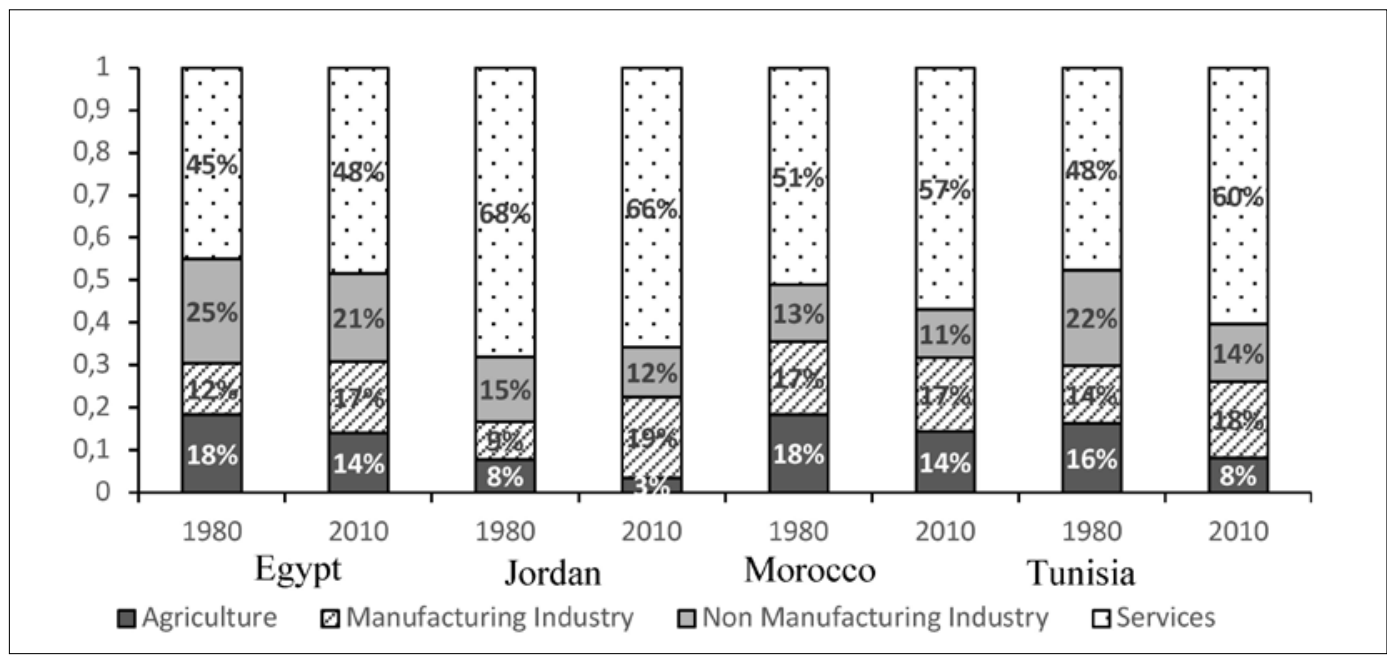

Source: World Development Indicators.

5 This paper focuses only on Egypt and Jordan. We include Tunisia and Morocco in this part for the sake of comparison. 
Figure 2 - Sectoral Employment 2011 (percentage of total employment).

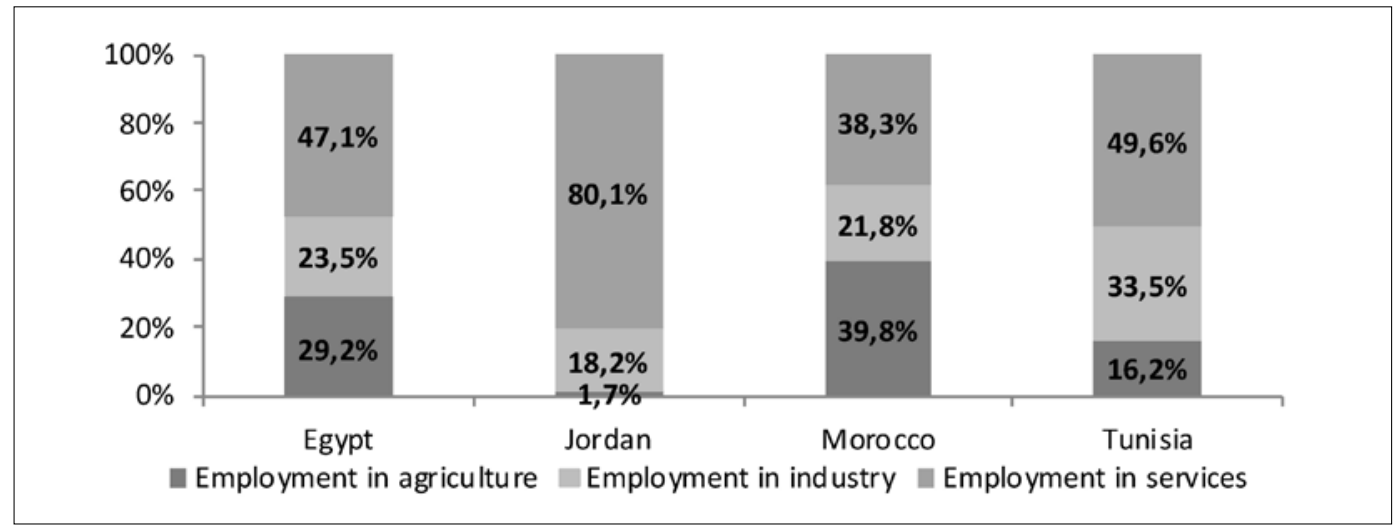

Source: World Development Indicators.

university and high institutes' graduates were offered jobs in the expanding government and public sector (El-Ehwany and Metwally, 2001; Radwan, 1997).

In an attempt to accelerate economic growth, the government initiated a new "open-door" policy in 1974 with the ultimate aim of encouraging the private sector and foreign investors to engage in economic activity. To serve that purpose, the government provided tax exemptions, allowed for the repatriation of profits, and guaranteed immunity from confiscation (Bolbol et $a l ., 2005)$. In addition to the policy reform, this period was also characterized by a drastic rise in foreign earnings from Suez Canal, petroleum exports, as well as workers remittances from abroad (Dobronogov and Iqbal, 2005). As a result, high rates of GDP growth were maintained throughout the 1975-1985 period with an annual average of $8.4 \%$.

Despite these remarkable growth rates, this period marks the beginning of unemployment problem in Egypt. This period is usually referred to as the "jobless growth decade" since the high levels of economic growth were accompanied by increasing unemployment rates, ranging around $4.6 \%$ per year, despite the fact that this period has witnessed a peak in Gulf states' demand for Egyptian migrant workers on the back of the increase in oil prices (Radwan, 1997). This can be explained considering the industrial policies that were implemented during this period, in which the artificially low costs of capital and energy subsidies have raised the rate of return on investments in the capital-intensive sectors relative to the labor-intensive ones, making capital-intensive industries relatively more attractive to investors. In addition to that, the government was facing fiscal difficulties in securing sufficient funds to finance the growing employment in the public sector (WB, 2014).

The growth path was then interrupted in 1986 when oil prices collapsed. As a result, Egypt's main sources of foreign currency - mainly oil exports, Suez Canal, and workers' remittances were undermined and the economy's growth rate declined to an annual average of $3.9 \%$ until the end of the 1980s (Bolbol et al., 2005).

In 1991, Egypt launched the Economic Reform and Structural Adjustment Program (ERSAP) with the support of World Bank and International Monetary Fund (IMF), with several goals in mind; to stabilize the economy, reduce inflation and stimulate medium and long-term growth. The reform program promoted liberalized market policies; involving the privatization of state owned enterprises (Fadel, 2011). These reform efforts succeeded in maintaining a moderate level of GDP growth rates with an annual average of $4.6 \%$ until the end of the $1990 \mathrm{~s}$. Nevertheless, these reforms were not sufficient to reduce unemployment which increased gradually over the following three years - being affected also by the net return migration after the Gulf war in 1990-1991 - and peaked in 1995 to an annual rate of $11 \%$ (Radwan, 1997). The 1991 
reforms were interrupted by a series of negative external shocks; starting with Luxor terrorist attack, followed by the Asian financial crisis, and later the events of September 11 which collectively worsened the economic situation in Egypt (Nassar, 2011). During the period 2000-2003, investments slowed down, and economic activity decelerated to an average growth rate of around $3.6 \%$ per year.

The reform path was accelerated once again, as the government implemented an economic reform program in 2004 that resulted in a sharp rise in foreign direct investments (FDI) inflows. Thanks to this reform, the stagnation in growth since 2000 was broken in 2004, as shown in figure 3, where the real GDP growth rate reached $4.1 \%$ compared to $3.2 \%$ in the previous year. Real GDP continued to grow achieving 4.5\% and $6.9 \%$ in 2005 and 2006 respectively and recording about $7.2 \%$ in 2008 . This surge in economic growth has resulted in a rise in overall employment and unemployment rate declined slightly from $11.2 \%$ in 2005 to $8.5 \%$ in 2008 .

As it can be noted from the above analysis, the Egyptian economy has not been growing evenly over the past five decades. However, even during periods of high GDP growth, this growth has not been matched with a significant employment growth. Instead, employment creation has been rather limited. Unemployment has remained at persistently high levels despite the significant economic growth that was achieved at various periods (Hassan and Kandil, 2011). Focusing on the two decades that witnessed two periods of economic reforms and vast economic progress (1990-2010), Figure 4 shows that unemployment has been increasing between 1991 and 1995 reaching a peak of $11 \%$ in 1995 and again between 1997 and 2006 reaching 10.5\% in 2006 . The rate then declined to $8.5 \%$ in 2008 before increasing once again as result of the financial crisis.

This persistent unemployment problem can be attributed to the demographic characteristics of Egypt (Nassar, 2011). Indeed, a potential explanation for the relatively high unemployment rates over the past two decades despite the favorable economic policies implemented is the large increase in the size of the labor force (WB, 2014). Over the 1990-2010 period, the Egyptian population has increased by almost $47 \%$ from 57.4 million in 1990 to 84.1 million in 2010 with an annual population increase of $2.2 \%$ a year on average. The labor force, on the other hand, has increased by $78 \%$ over the same period from 15.8 million in 1990 to 28.2 million in 2010 with an annual growth rate of $3.7 \%$ per year on average. The faster growth rate of labor force indicates that a large proportion of the Egyptian population is young with a large number of young people entering the labor force each year searching for their first jobs. However,

Figure 3 - GDP Growth rate (\%).

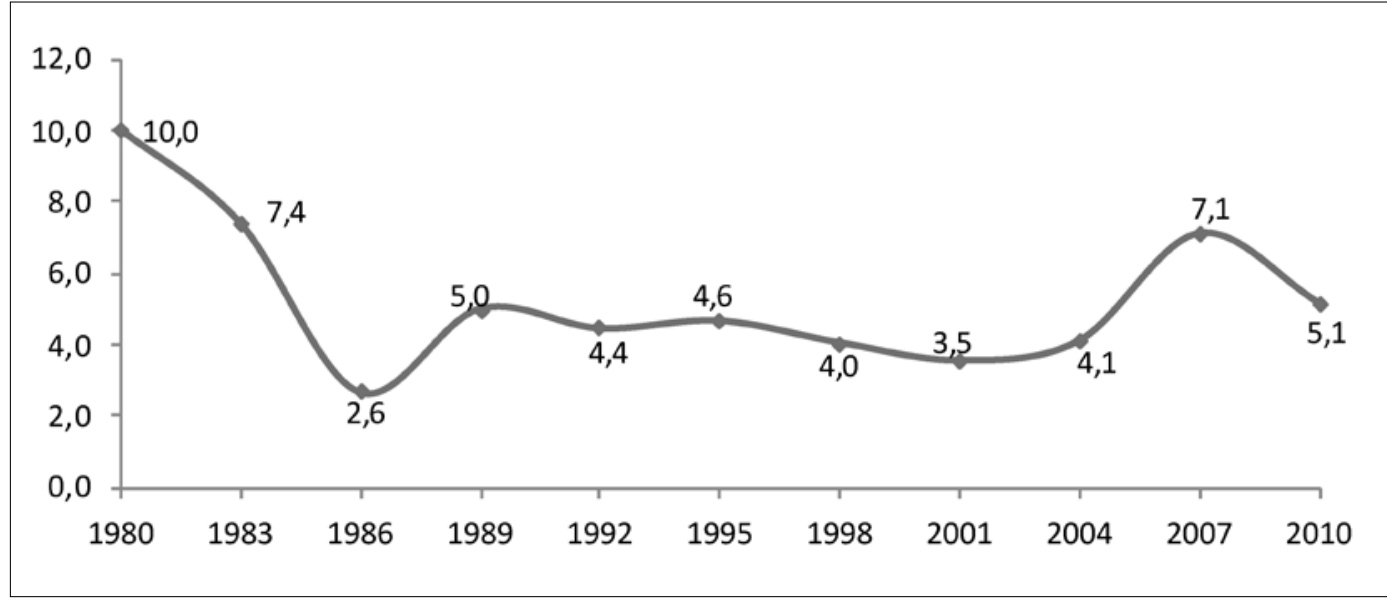

Source: World Development Indicators. 
Figure 4 - Unemployment rate (\%).

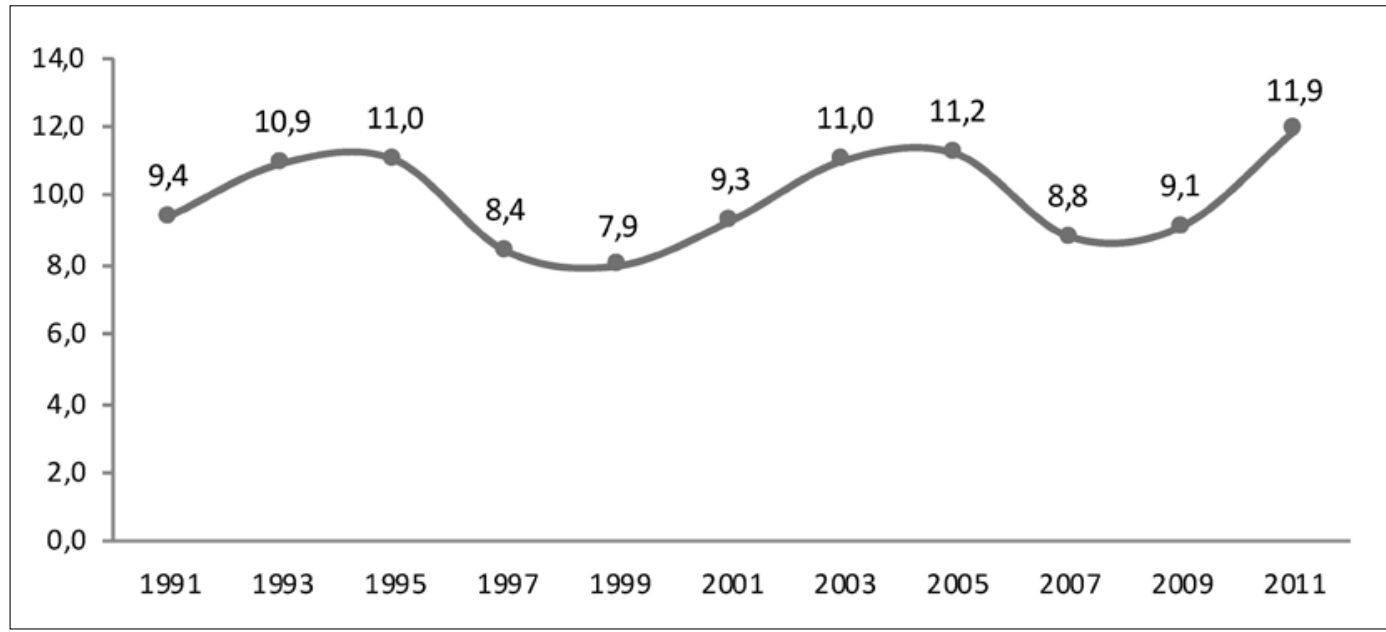

Source: World Development Indicators.

the rate as well as the composition of economic growth were insufficient to create the required employment opportunities, and this constitutes the second reason behind the persistency of the unemployment problem in Egypt (Hassan and Sassanpour, 2008; Nassar, 2011).

At the sectoral level, Figures 5 and 6 reflect the distribution of GDP and total employment by economic activity, respectively. As displayed by the two figures, the share of agriculture, forestry, and fishing sector - a labor-intensive sector - in both output and employment has been declining over time. With regard to output, after contributing with $18.5 \%$ of total GDP in $1985-1986$, this share declined to $14 \%$ in 2005-06. As for employment, the share of total employment in the agriculture sector decreased by almost $10 \%$ from $36.7 \%$ in $1985-86$ to $27.3 \%$ in $2005-2006$. This decline suggests that employment has shifted away from the agriculture sector either due to workers' migration to the Gulf States or due to urban migration and joining the manufacturing sector (El-Ehwany and Metwally, 2001).

In contrast, the contribution of manufacturing industries sector - another labor-intensive sector - in both output and employment has been increasing over the selected period. However, the increase in the sector's share of GDP has been larger than the increase in its share of to- tal employment. This can be attributed to the expansion of using capital intensive techniques in manufacturing (El-Ehwany and Metwally, 2001). The share of manufacturing in GDP has risen from $15.3 \%$ in $1985-1986$ to $17 \%$ in 2005 2006 - with a peak of $19 \%$ of GDP in 2000-2001 - attracting at the same time a larger share of total employment which rose from $11 \%$ in 1985 1986 to $13 \%$ in $2005-2006$.

Unlike the agriculture and manufacturing industries sectors where the changes in both output and employment were moving in the same direction, the construction and building sector displayed a distinctive pattern for each of them. While the sector's share of GDP has been gradually decreasing over time from $5.5 \%$ in 1985 1986 to $4.1 \%$ in $2005-2006$, the sector's share in total employment has been steadily increasing from $4.6 \%$ in $1985-1986$ to $7.8 \%$ in $2005-2006$. And finally, for the transportation, communication, and information sector, both output and employment shares have been relatively stagnant over time ranging around $6.6 \%$ of total GDP and $4.3 \%$ of total employment on average.

Thus, combining the growth and employment figures together, between 1985-1986 and 20052006, GDP has grown by more than $90 \%$. Employment, on the other hand, has grown by only $67 \%$ over the same period, over which around 7.9 million jobs were created, suggesting that 
Figure 5 - GDP distribution by economic activity.

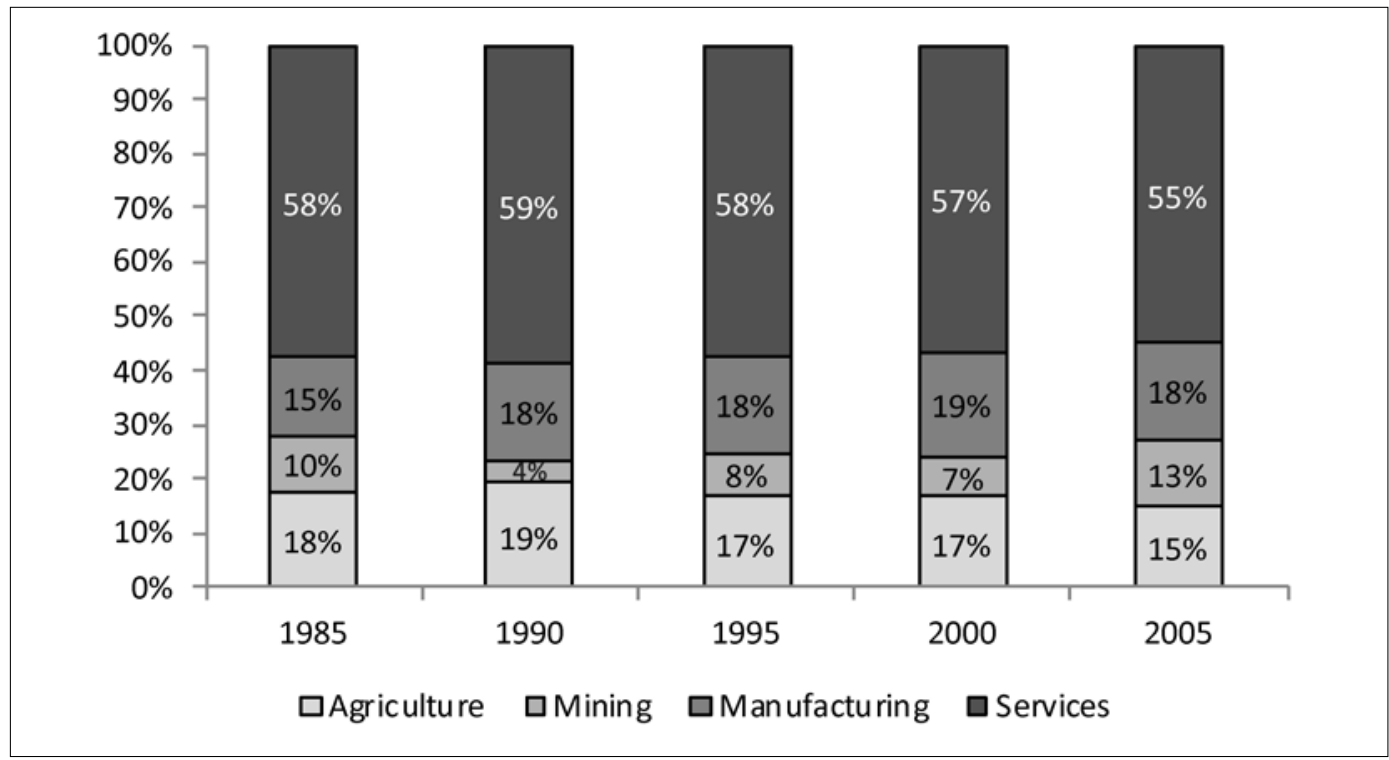

Source: Authors'calculations based on data from Ministry of Planning and Ministry of Economic Development.

Figure 6 - Employment distribution by economic activity.

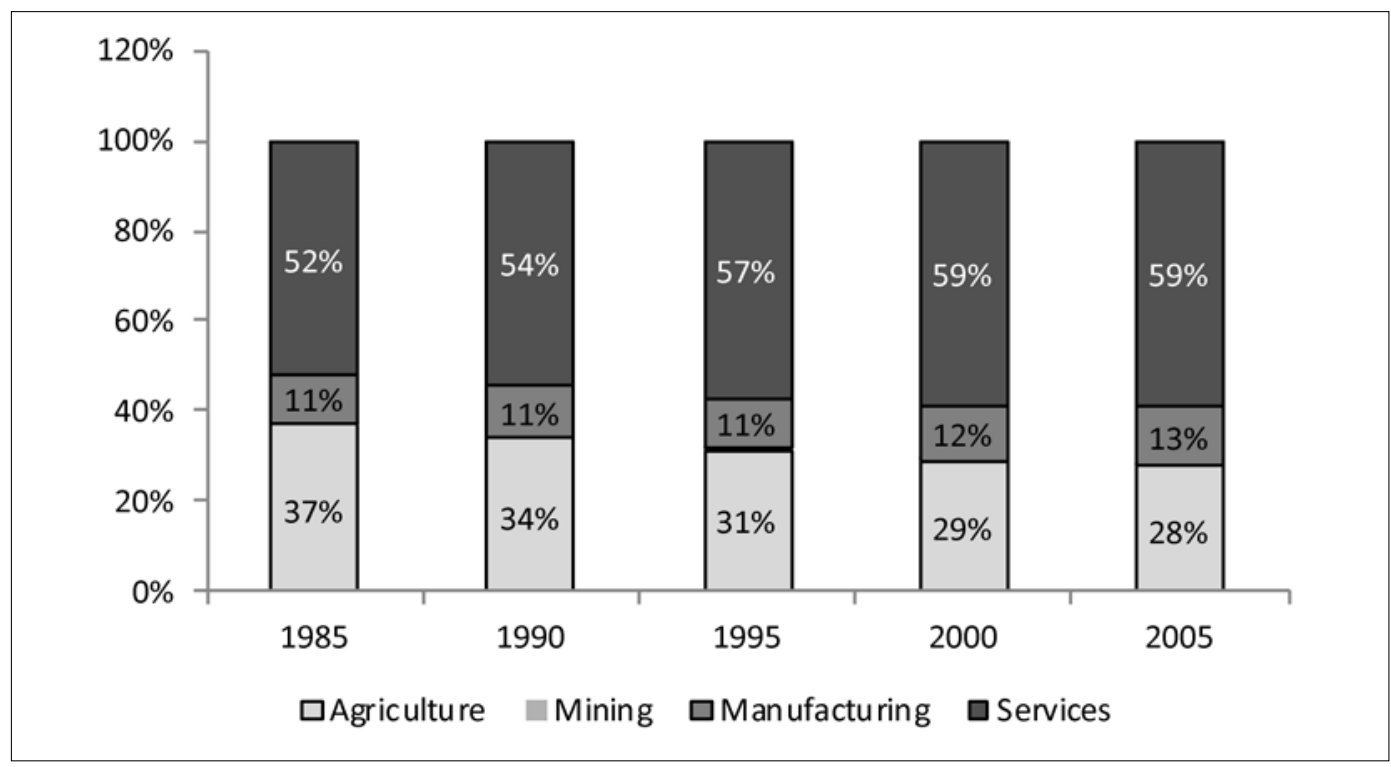

Source: Authors'calculations based on data from Ministry of Planning and Ministry of Economic Development.

the employment intensity of growth was not sufficient to create enough job opportunities and ease the unemployment problem.

As per Jordan, it is a small country of the Middle East, poor of natural resources, almost $79 \%$ of its area is semi-desert and is the third water poorest country of the world (UN, 2014). According to the 2016 census, population is 9.5 million and consists of 6.6 million Jordanians and 2.9 million non-Jordanian residents. In 2017, GDP was JD 28.5 billion, i.e. roughly US\$ 40 billion. Jordan is classified as an upper 
Figure 7 - GDP growth in Jordan at constant market prices (\%).

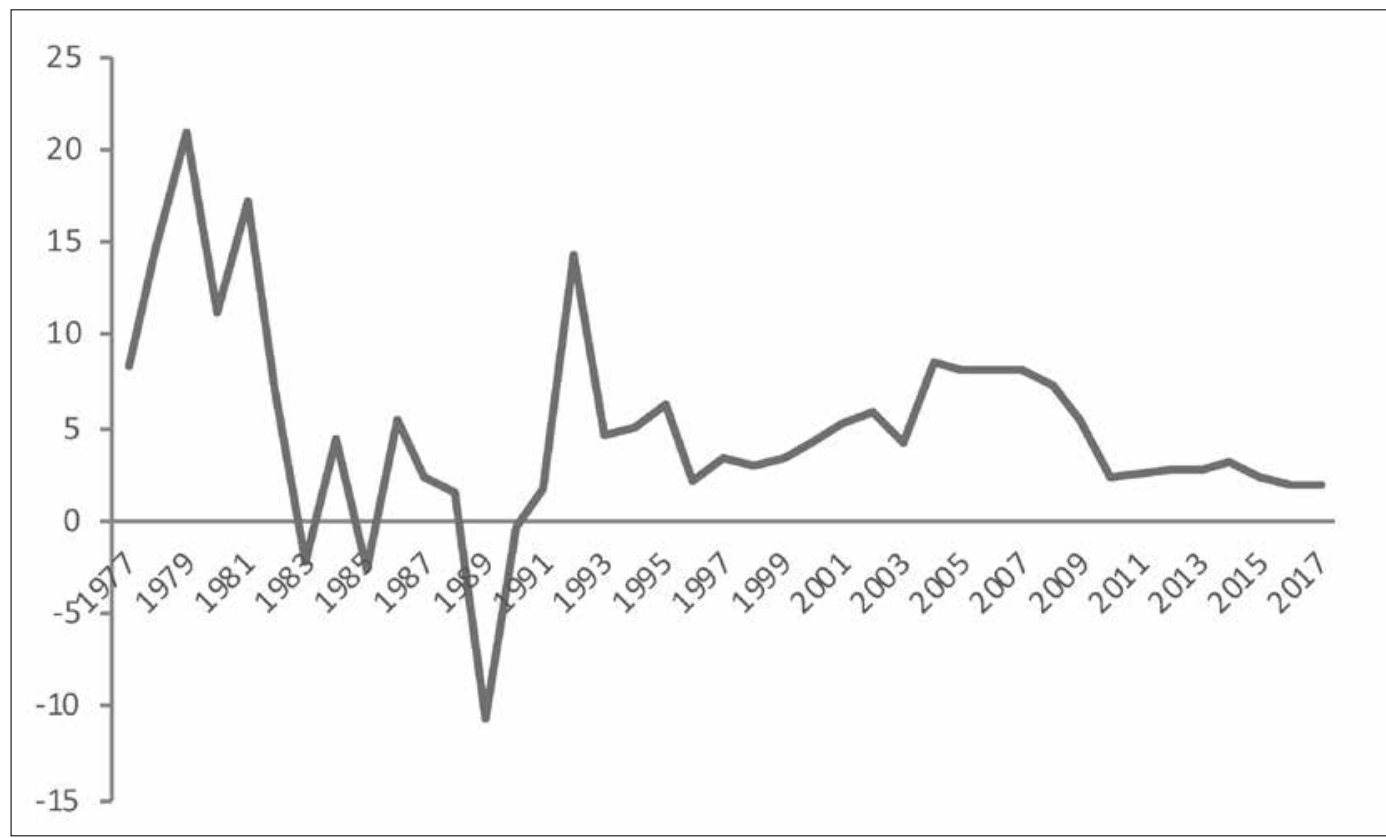

Source: Central Bank of Jordan

middle-income country and, in 2017, per capita GDP was JD 2,830 (US\$ 3,990).

The oil boom of the 1970s led to an increase in both the international aid accruing to Jordan from the oil exporting Arab countries and in the remittances from Jordanians working in the Arab Gulf. Between 1975 and 1981, Jordan perceived aid and remittances for an average of $47.6 \%$ of GDP. As Figure 7 shows, the massive inflow of external rent induced an average real economic growth between 1977 and 1982 almost 8.5\%. This economic boom enabled the state to tighten its control on the economy, to expand its apparatus, and to pursue a generous employment policy (Alshyab, 2012).

Economic growth started to slow down at the beginning of the 1980s as a result of the sharp decline in oil prices which, in turn, resulted in a decline in the remittances of Jordanian workers as well as in the reduction of financial assistance from Arab countries. These developments culminated in 1989 in a deep financial crisis, which saw a drastic devaluation of the Jordanian Dinar, a large deficit in the balance of payments, and the exhaustion of external reserves. In addition, public debt jumped to $225.1 \%$ of GDP and debt services reached in 1988 a debt service ratio of $37.9 \%$ (Central Bank of Jordan, 1991).

The rise in unemployment over this period can be attributed to several factors. The decline in economic activity as a result of the economic crisis has curtailed the economy's ability to create new job opportunities. The problem was further aggravated as about 300,000 Jordanian workers returned from the Gulf States after the outbreak of the Gulf war in 1990, in addition to the large inflows of foreign workers which together have substantially increased the number of entrants to the labor market and consequently the unemployment rate (Amerah and Khasawneh, 1993; Alshyab, 2012).

To overcome the crisis, Jordan, similarly to Egypt, started to implement in 1990 a comprehensive economic reforms program under the umbrella of IMF. As a result, economic growth was on average 5.5\% between 1993 and 2009 (authors' calculations based on data by the Central Bank of Jordan). Despite of the big efforts 
and progresses Jordan did in implementing reforms, unemployment, public debt and chronic budget deficit remain among the most serious challenges for the country.

Since the financial crisis of 1989, unemployment did not decrease below 10\% (see Figure 8). In 2017, it has increased from $15.3 \%$ of 2016 to $18.3 \%$. The age group that is most affected by unemployment is the youth: unemployment rate among people aged 20-24 is namely almost $40 \%$. Unemployment rate for female youth is even higher. There is thus an urgent need to create new jobs in the country, in particular considering the massive inflow of refugees and the young and steadily growing population. The present analysis is thus extremely policy relevant, as it should help to understand how to increase the job content of economic growth.

As in the figures above (Figures 7 and 8) and similarly to the Egyptian case, despite the steady increase in the growth rates as a result of the economic reforms, the unemployment rate has not remarkably decreased and remained persistently high. This signals that economic growth alone was insufficient to resolve the unemployment problem.
In particular, several factors need to be taken into consideration in regard to unemployment in Jordan: the disdain towards manual jobs persists and can partly explain the large number of foreign workers, who are mostly employed in construction, agriculture, and domestic services. Currently it can be estimated that there are more than 320,000 migrant workers in Jordan holding a regular working permit. However, unofficial estimates report a total number of 750,000 foreign workers. On the one hand, economic growth has failed in Jordan to create enough jobs and, on the other hand, skills mismatch is hampering economic growth. In general, there is a gap between the skills offered by job seekers and the skills required by the labor market. In particular, the Jordanian labor market seems to be both characterized by a sort of over-education and by under-skilling. Over-education is revealed by the high unemployment rate among graduates, while under-skilling is revealed by the high unemployment rate among individuals with less than secondary education (notwithstanding a large number of foreign workers, that are mostly active in manual and non-qualified jobs) (Alshyab et al., 2018).

Figure 8 - Unemployment rate in Jordan (\%).

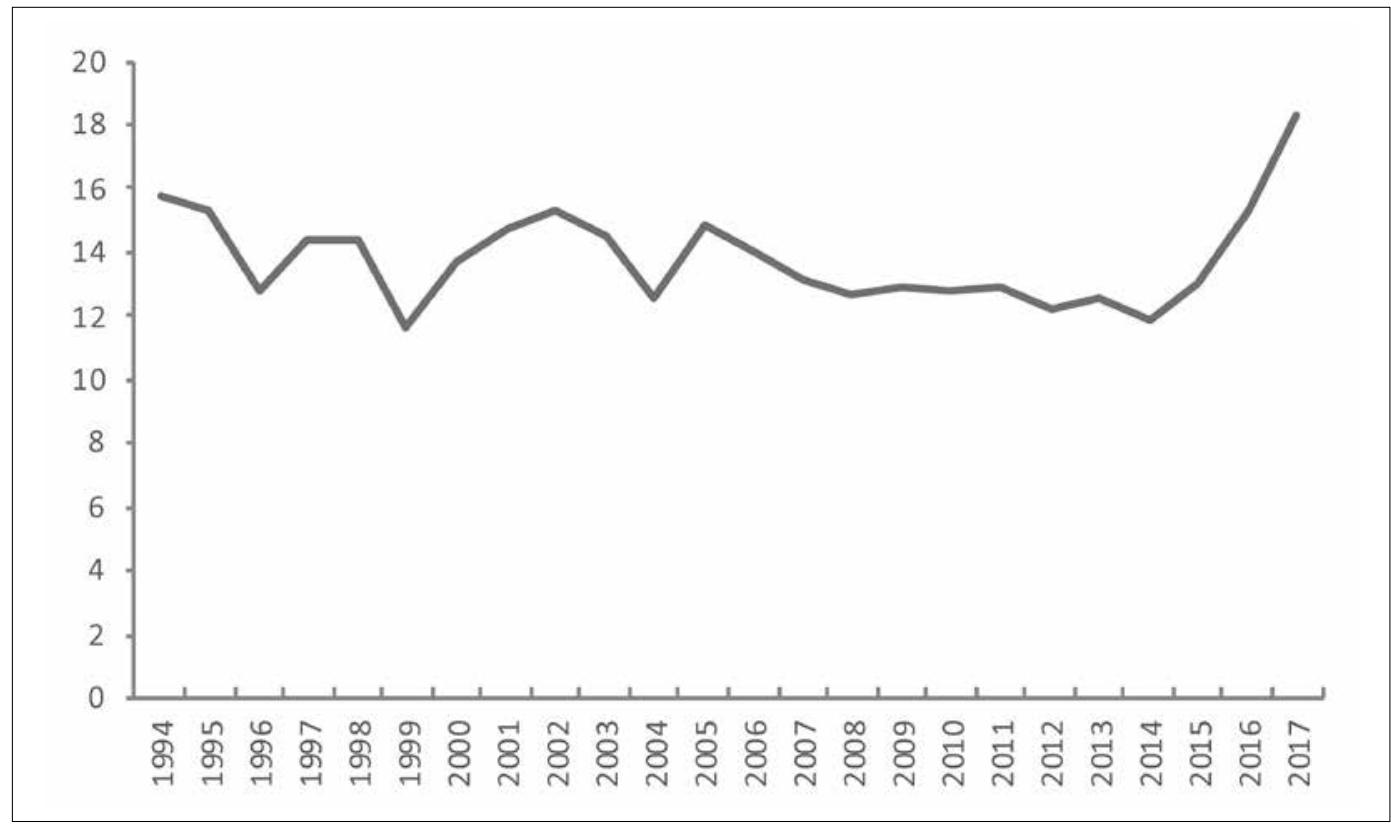

Source: ILO. 
Another factor that has contributed to the high unemployment rates is the structure and composition of economic growth. The economic liberalization and the export-promotion strategy that was implemented in Jordan has focused on improving the competitiveness of the Jordanian exports. This has resulted in lower wages and poor working conditions making the newly created job opportunities less attractive to the Jordanian workers. These low-paid jobs are often filled up by migrants making them a favorable option for most employers while leaving many Jordanians unemployed. In addition, the high educational attainment of most Jordanians has raised their expectations about the suitable job opportunities for them making them less employable (Taghdisi-Rad, 2012).

Figures 9 and 10 present the evolution of GDP distribution by economic activity vis-à-vis the respective employment contribution in Jordan. It emerges that, as a result of privatization and public administration reform, public administration (including defense, public education, and public health) has reduced its contribution to GDP as well as its share of employment. Still, the public sector in Jordan remains one of the most employment intensive sector. Over $38 \%$ of Jordanian employees are working in the public sector. Wholesale and retail trade can be further characterized as labor intensive sector, even though its GDP contribution has not considerably increased, its employment share is increasing over time and surpasses GDP contribution. Thus, the employment in these two sectors reveals that services are very important for employment in Jordan.

Manufacturing has increased its value-added creation, but its employment share did not rise. The growth in the manufacturing sector, where FDI are among else mostly directed, did not result into job creation. Financial services and intermediation have increased their contribution to GDP to $11 \%$ circa, vis-à-vis an employment share of less than $2 \%$. This sector has experienced a sharp growth but can be definitely characterized as capital intensive. As a general note, the agricultural sector is not included in the employment statistics by the Jordan Department of Statistics. However, both GDP contribution and employment creation by the agricultural sector in Jordan are negligible: according to the Central Bank of Jordan, GDP contribution of agriculture was in 2017 less than 4\% and employment was $1.9 \%$. It should be further considered that the agricultural sector mostly employs foreign workers.

In conclusion, economic growth might be a necessary but not a sufficient condition for employment creation. The composition of growth; or in other words the employment intensity of growth and its ability to generate jobs; is equally important (El-Ehwany and Metwally, 2001; Radwan, 1997).

\section{Overview of labor reforms}

This section provides an overview of labor market reforms in our countries of interest. First, in Egypt, in an attempt to promote job creation, the Egyptian government has pursued active labor market policies over the years by setting up several training and employment programs. Yet, their effect was rather limited as it will be explained below.

Among the examples usually cited, the Mubarak-Kohl training initiative was launched in the early Nineties to reform the secondary technical education system and match the needs of the labor market. The Ministry of Industry also organizes vocational training programs through its productivity and vocational training department (PVTD).

As for the employment programs, the Social Fund for Development (SFD) was created in 1991 as a joint initiative between the Egyptian Government, the World Bank, and the UNDP to alleviate the negative pressures of the structural reform program on the most vulnerable groups of the population and promote job creation. The fund runs several programs; among which is the Public Work Program (PWP) which provides funds to small labor-intensive infrastructure projects in rural and deprived urban areas with the ultimate aim of improving the business environment and attracting private investments to the local communities. The program has managed to create more than 6,000 permanent jobs and about 111,000 temporary ones over the 
Figure 9 - GDP distribution by economic activity in Jordan.

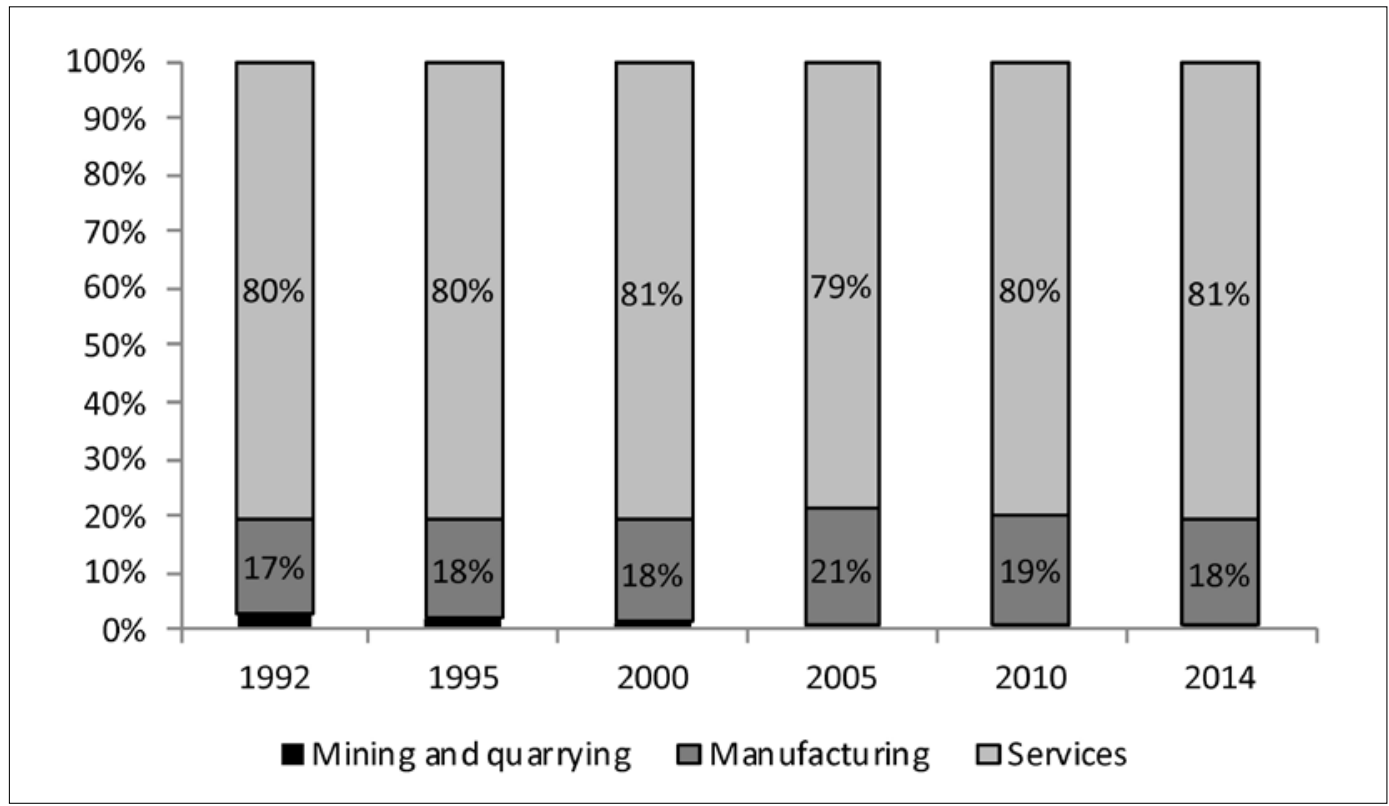

Source: Authors' calculation based on Jordan Department of Statistics, DoS.

Figure 10 - Employment distribution by economic activity in Jordan.

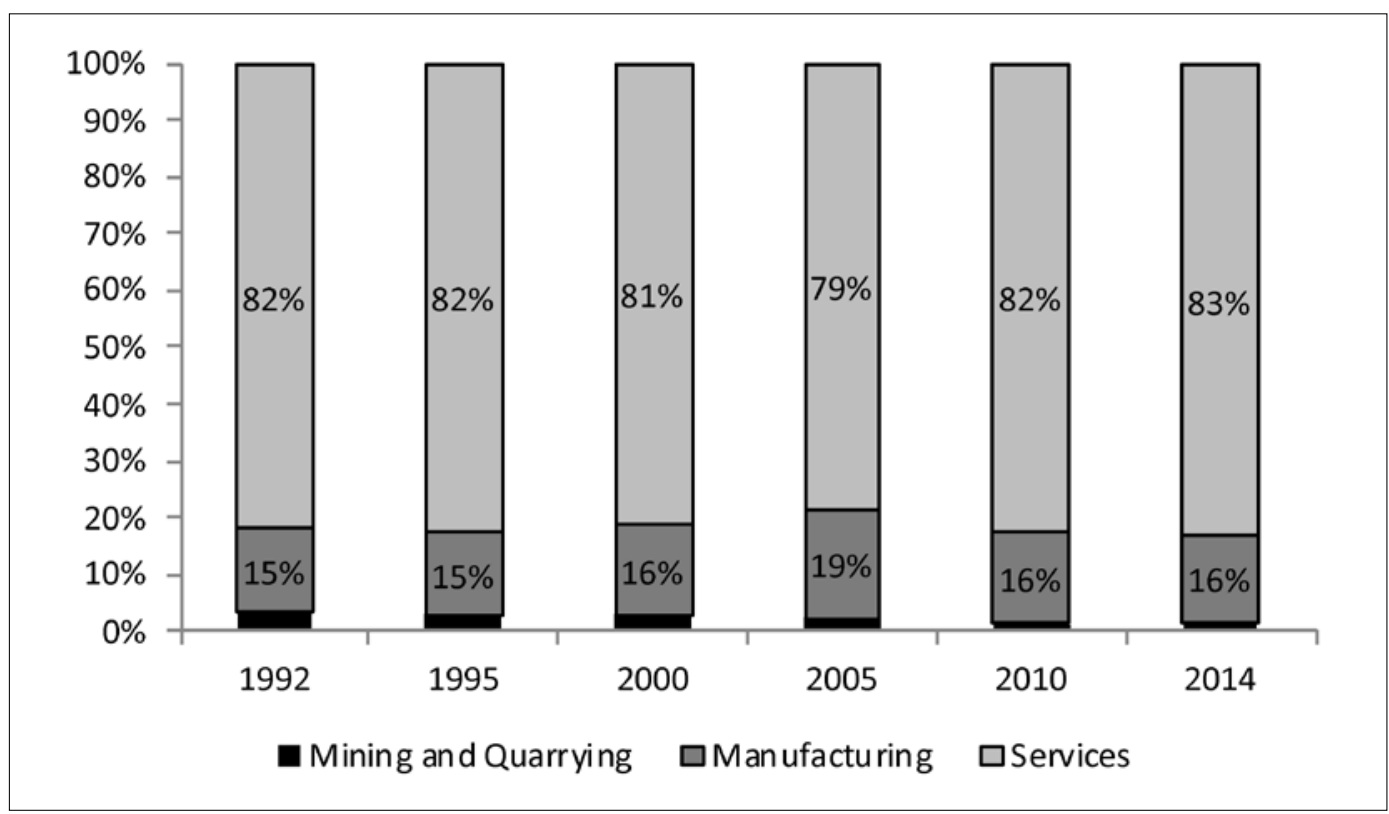

Source: Authors' calculation based on Jordan Department of Statistics, DoS.

1994-2000 period. In 2017, it became the SMEs is another employment program launched by Promotion Agency in order to boost entrepre- the government to promote job creation in runeurship and help Micro and SMEs expand. ral areas. Over the same period, the program has Furthermore, the "Sunrise" (Shorouk) program created 59,000 and 123,000 permanent and tem- 
porary jobs, respectively (De Gobbi and Nesporova, 2005). Other programs were also initiated but their main drawbacks were threefold. First, there was lack of funding which affected their sustainability. Second, they were not accompanied by other programs that provide job seekers with the required skills. Third, most of the efforts were either dispersed or uncoordinated.

Labor laws and regulations are also an important factor affecting the performance of the labor market. These laws can either worsen or soothe the rigidity of the labor market (El-Ehwany and Metwally, 2001). In an attempt to promote employment and job creation in the private sector, the Egyptian government introduced a new unified labor law "Law No. 12 for the year 2003" to address the issues that were viewed by both employers and employees as major shortcomings of the previous law No. 137 for the year 1981. Immense criticism has been directed toward the former labor law especially with regard to three central issues, namely; prohibiting employers from terminating workers' contracts after the end of the probation period, overlooking workers' rights to strike against deteriorating working conditions, and restricting trade unions' ability to efficiently negotiate in favor of workers' rights (El-Ehwany and Metwally, 2001; Guirguis, 2011).

Though the 2003 law has addressed all the aforementioned criticism - in terms of granting private sector employers a higher degree of flexibility in the hiring and firing procedures ${ }^{6}$ while at the same time improving workers' rights including their right to organize peaceful strikes and permitting collective bargaining between labor unions and private sector employers - it is still facing criticism by both parties of the employment relationship. Workers and labor unions, on one hand, see that the law needs to be reformed again to emphasize workers' rights in a more decisive manner. While investors and employers, on the other hand, perceive the law as being biased toward workers with several ambiguities in its articles that can ultimately hinder employment (Guirguis, 2011; Lacey and Abdel Aziz, 2015; U.S. Department of State, 2014).

These ambiguities are particularly evident in the articles regulating the termination of employees, the dispute settlement mechanism, and the financial entitlements of workers (Lacey and Abdel Aziz, 2015). Some ambiguities are still present in the new law with regard to workers compensation due to early termination. In case of early termination of indefinite contracts, the law states that workers are entitled to a termination compensation of a minimum two month of their last gross salary for each year of service that is to be decided by the competent judge based on the evidence submitted by each party. The law, however, has not specified any compensation criteria for the early termination of definite term contracts and has left it entirely to the judge's discretion (Lacey and Abdel Aziz, 2015).

The second source of criticism toward the new law is its dispute settlement mechanism. A complex and prolonged settlement mechanism is outlined in the law. First, a three-member committee has to be formed within 10 days from submitting the settlement application; comprising of representatives of the Ministry of Manpower or labor office, the labor union, and the employer's organization. If the committee was not able to reach any accepted settlement within 21 days from the submission date, then the dispute shall be transferred to the labor court based on the request from either the employer or the employee with no specified time limit for the resolution (Lacey and Abdel Aziz, 2015).

The last source of criticism is directed by private sector employers with regard to the financial rights entitled to employees under the new law. The law broadly defines "gross salary" as "everything the employee receives from the em-

${ }^{6}$ The 2003 Law has entitled private sector employers the right to terminate workers with definite term contracts once the contract expires without any warning or prior notice. As for the indefinite employment contracts, employers cannot dismiss workers except for a cause with a 60 days dismissal notice. The Law has listed an exhaustive list of justified termination causes including poor performance (Guirguis, 2011; ILO, 2006; Lacey and Abdel Aziz, 2015). Furthermore, the law allows employers to renew the contracts of temporary employees without any obligation to convert them into permanent staff, as was postulated by the former law (Guirguis, 2011; Sharkawy and Sarhan, 2017). 
ployer in consideration of his work, whether it is basic or variable, cash or in kind" without any exhaustive list of the items that can be considered part of employee's salary. This means that any additional benefit offered by the employer on a general, continuous and consistent manner, even if not stipulated by law or stated in the contact, will become an acquired right for the employee and an obligation that the employer has to fulfill. The lack of any article determining the time length after which any additional benefit can be considered an acquired right opens the door for disputes between the two parties of the employment contract (Lacey and Abdel Aziz, 2015; Sharkawy and Sarhan, 2017).

As per Jordan, the main goal of the National Agenda for 2006 to 2015 was to improve the quality of life of the Jordanian citizen through "improving standards of living, providing social welfare and social security, and providing new job opportunities" (National Agenda, 20052015). The agenda prescribed the creation of the Employment, Technical and Vocational Education and Training (E-TVET) Council, which was thought as an umbrella under which all of the bodies involved in training, vocational, and technical education should act. Important steps were also the establishment of the Centre for Accreditation and Quality Assurance (CAQA) and the launch of Employment-Technical and Vocational Education and Training E-TVET Strategy 2008-2013, followed by a new strategy for the time frame 2014-2020.

The focus on employment is confirmed by the formulation of the specific National Employment Strategy (NES) 2011-2020, which derives its vision from the National Agenda. The NES vision consists of "improving standards of living for Jordanians, through increased employment, wages and benefits, and productivity improvements" (NES, 2011). The key public institutions related to the labor market are the Ministry of Labour, the E-TVET Council and Fund, the Vocational Training Corporation, the Civil Service Bureau, and the Social Security Corporation.

Labor market reforms and its strategic orientation have been partly designed in close cooperation with international institutions and agencies, such as the World Bank, the European Union, the US Agency for International Development (USAID), and the International Labour Organization (ILO).

The Jordan National E-TVET Strategy (2014), however, points out that there are "too many academically qualified Jordanians while the market asks for lower skilled labor and technicians." This mismatch is aggravated by the fact that the profile of university graduates is not providing the practical skills required by the labor market: "their education does not match with the demands of the industry even in the corresponding professions as the skills learned are too academic and not sufficiently practical" (Jordan National E-TVET Strategy, 2014).

Vocational education and training have failed to become a coordinated and effective field under a single umbrella. Further, an underlying problem with vocational training in Jordan is that it is still associated with "the stigma of academic failure" (NES, 2011) and relates thus to the unproductive bias, culture of shame, and widespread aversion to manual jobs (Alshyab, 2012). This is also the case in Egypt. In addition, or, better, as a corollary, vocational training has so far failed to systematically reach females and it has been predominantly attended by foreign workers. Further, trainings are mostly administered in a pretty academic way, thus putting much emphasis on exams and on school alike skills rather than on practical skills and competencies. In general, VET is organized, promoted, and administered by public bodies, with only a marginal role played by private entities (NES, 2011).

Therefore, this analysis shows to what extent both the Jordanian and the Egyptian labor markets had three similar characteristics. First, both had vague strategies and unsustainable reforms. Second, vocational education and training lacked the attention it deserves. Third, and consequently, unemployment levels were rather high despite periods of economic growth.

\section{Model and data}

To provide a measure of the employment intensity of growth for the different sectors in Egypt and Jordan, we use the methodology adopted by Goaied and Sassi (2015). We estimate the em- 
ployment intensity of sectoral output growth using a linear demand model where the number of employees in each sector is regressed on its value added, according to the following equation:

$$
\begin{aligned}
& E M P_{i t}= \alpha_{i}+\beta_{i} V A_{i t}+\varepsilon_{i t} \\
& \mathrm{i}=1 \ldots \mathrm{N} \text { and } \mathrm{T}=1 \ldots \mathrm{T}
\end{aligned}
$$

To prevent any problems of non-stationarity in the variables included in the equation (2), we use a first-difference Model, defined as follows:

$$
\begin{aligned}
\Delta E M P_{i t}= & \beta_{i} \Delta V A_{i t}+\Delta \varepsilon_{i t} \\
& \mathrm{i}=1 \ldots \mathrm{N} \text { and } \mathrm{T}=1 \ldots \mathrm{T}
\end{aligned}
$$

Since the variables are expressed in logarithmic form, the coefficient $\beta_{i}$ measures the employment intensity of output growth for sector $i$. $\varepsilon_{i t}$ are residuals supposed independent and identically distributed as normal, with mean 0 and variance $\sigma_{i}^{2}$. To control for the heterogeneity of the sectors, we use a random coefficient Model, where the coefficient $\beta_{i}$ is treated as random with mean $\bar{\beta}$. Swamy (1970) supposes that:

$$
\begin{aligned}
& \beta_{i}=\bar{\beta}+\delta_{i} \\
& E\left(\delta_{i}\right)=0 \\
& E\left(\delta_{i} \delta_{i}^{\prime}\right)= \begin{cases}\Omega \text { if } & i=j \\
0 \text { if } & i \neq j\end{cases} \\
& E\left(V A_{i t} \delta_{i}\right)=0
\end{aligned}
$$

Since we, are interested in the individual coefficient $\beta_{i}$ because it provides information on the behavior of each sector, Hsiao (2014) proposed to predict $\beta_{i}$ by the Best Linear predictor suggested by Lee and Griffiths (1979), defined as follows:

$$
\hat{\beta}_{i}^{*}=\hat{\bar{\beta}}_{G L S}+\left(\Omega X_{i}^{\prime}\left(X_{i} \Omega X_{i}^{\prime}+\sigma_{i}^{2} I_{T}\right)\left(Y_{i}-X_{i} \hat{\bar{\beta}}_{G L S}\right)\right)
$$

We note that $Y_{i}=\left[\Delta E M P_{i t}\right]$ and $X_{i}=\left[\Delta V A_{i t}\right]$

Data on employment and added value are annual and expressed at constant prices.

\section{Empirical findings}

The interest of this empirical analysis is to highlight the structural evolution of the contribution of different sectors of activity to the creation of employment by understanding the links with the productivity of work. We will chiefly analyze the RCM column as it is the most econometrically robust.

In general, it is worthy to note that the manufacturing sector is one of the most important sectors that create jobs especially for Egypt (see Table 2). Indeed, the manufacturing sector boosts productivity growth faster than services and generates well-paid jobs with several skills and professions. Second, the manufacturing sector uses also a lot of services inputs. Third, manufacturing also drives technological change and consequently can increase the demand for skilled labor. As per services, tourism is also ranked among the first sectors that create jobs as these economies rely on tourism as a source of foreign currency. In general, the elasticity of employment intensity and added value ranges from 0.67 to 0.4 for service activities, namely: financial, insurance and real estate activities (0.67) and employment activities, hotels and restaurants as well as buildings and public works $(0.45-0.43)$. For both

Table 1 - Summary of findings.

\begin{tabular}{|cll|}
\hline & Egypt & Jordan \\
\hline 1 & Manufacturing & Administration \\
\hline 2 & $\begin{array}{l}\text { Construction \& } \\
\text { Building }\end{array}$ & Hotels and Rest. \\
\hline 3 & Electricity & Real Estate \\
\hline 4 & $\begin{array}{l}\text { Transportation, } \\
\text { Storage, } \\
\text { Communication } \\
\text { and Information }\end{array}$ & Construction \\
\hline 5 & $\begin{array}{l}\text { Other } \\
\text { Cot sig. }\end{array}$ & $\begin{array}{l}\text { Community, Social } \\
\text { and Personal } \\
\text { activities }\end{array}$ \\
\hline 6 & $\begin{array}{l}\text { Real Estate } \\
\text { Activities }\end{array}$ & Education \\
\hline Noting & Mining \\
\hline
\end{tabular}

Source: Authors'own elaboration. 
Table 2 - The employment intensity of sectoral output growth in Egypt.

\begin{tabular}{|c|c|c|c|c|c|c|}
\hline & Sectors & $O L S$ & & $R C M$ & & Rank \\
\hline & & (1) & & (2) & & (3) \\
\hline 1. & Agriculture, forestry \& fishing & 0.432 & $(0.033)$ & $0.066^{* *}$ & $(0.033)$ & 7 \\
\hline 2. & Mining & $0.566^{* * *}$ & $(0.089)$ & 0.075 & $(0.052)$ & - \\
\hline 3. & Manufacturing Industries & $0.771 * * *$ & $(0.037)$ & $0.317 * * *$ & $(0.059)$ & 1 \\
\hline 4. & Electricity & $0.511 * * *$ & $(0.033)$ & $0.217 * * *$ & $(0.043)$ & 3 \\
\hline 5. & Construction \& Building & $1.819 * * *$ & $(0.184)$ & $0.242 * * *$ & $(0.075)$ & 2 \\
\hline 6. & Transportation, Storage, Com. and Inf. & $0.896 * * *$ & $(0.064)$ & $0.216 * * *$ & $(0.062)$ & 4 \\
\hline 7. & Suez Canal & $-0.040 * *$ & $(0.023)$ & -0.002 & $(0.031)$ & - \\
\hline 8. & Restaurants \& Hotels & $0.374 * * *$ & $(0.061)$ & 0.082 & $(0.064)$ & - \\
\hline 9. & Real Estate Activities & $1.095 * * *$ & $(0.124)$ & $0.160 * *$ & $(0.067)$ & 6 \\
\hline 10. & Other & $0.884 * * *$ & $(0.075)$ & $0.185 * * *$ & $(0.064)$ & 5 \\
\hline
\end{tabular}

Notes: (i) OLS: ordinary least squares; RCM: random coefficient models.

(ii) Standard errors are in parenthesis.

(iii) ***,**and * indicate significance levels at $1 \%, 5 \%$ and $10 \%$, respectively.

countries, the mining sector is insignificant. Indeed, this shows to what extent this sector is capital intensive, does not have a significant value-added and thus does not create jobs.

For the Egyptian case, Table 4 shows that manufacturing industries are the most likely sector to create jobs followed by construction and building. Surprisingly, the tourism sector is not significant in Egypt as it is still facing several impediments that hinder its competitiveness.

A more detailed look at each country shows that services play a more important in Jordan compared to Egypt (see Table 3). Indeed, Jordan is much more competitive than other MENA countries in the services sectors as it is shown in Figure 11. Moreover, Jordan is the country that has the highest number of commitments at the WTO which makes its services sector the most liberalized in the MENA region and hence the most competitive (Figure 11). Indeed, according to the GATS agreement, when making a commitment a government therefore binds the specified level of market access and national treatment and undertakes not to impose any new measures that would restrict entry into the market or the operation of the service.

Regarding the decomposition analysis, Ta- ble 4 shows that, generally, in Egypt, employment growth has been the major source of value-added growth. On average, while productivity growth explains $30 \%$ of growth in value-added, employment growths explains $70 \%$ of it. At the sectoral level, more heterogeneity can be observed: six sectors experienced a higher employment growth (mining, manufacturing, construction, transport, real-estate and other services) and 4 sectors productivity growth (agriculture, electricity, Suez Canal and tourism). Indeed, while construction and real estate experienced negative productivity growth, tourism and Suez Canal had the highest growth of labor productivity over the period 1980-2010.

As per Jordan, employment growth was sustained in trade, hotel and restaurant, real estates, construction, and other services. Whereas labor productivity growth was in general lagging, the sector with the highest labor productivity growth was financial intermediation: this sector registered a steady increase in its contribution to GDP growth not backed up by an increase in employment. Further, despite privatization and public administration reform, the public sector in Jordan remains one of the most employment intensive sector (see Table 5). 
Table 3 - The employment intensity of sectoral output growth in Jordan.

\begin{tabular}{|c|c|c|c|c|}
\hline & Sectors & $O L S$ & $R C M$ & Rank \\
\hline & & (1) & (2) & (3) \\
\hline 1. & Mining and Quarrying & 0.08 & 0.04 & - \\
\hline 2. & Manufacturing & $0.90 * * *$ & $0.42 * *$ & 7 \\
\hline 3. & Electricity and Water Supply & $0.137 * * *$ & 0.06 & - \\
\hline 4. & Construction & $1.63 * * *$ & $0.655^{* * *}$ & 4 \\
\hline 5. & Wholesale and Retail Trade, Repair of Motor V. & $2.32 * * *$ & $0.41 *$ & 8 \\
\hline 6. & Hotels and Restaurants & $1.42 * * *$ & $0.78 * * *$ & 2 \\
\hline 7. & Transport, Storage and Communications & $0.304 * * *$ & 0.288 & - \\
\hline 8. & Financial Intermediation & $0.35^{* *}$ & 0.16 & - \\
\hline 9. & Real Estate, Renting and Business Activities & $2.95^{* * *}$ & $0.68 * *$ & 3 \\
\hline 10. & Public Adm., Defense, and social security1 & $0.95^{* * *}$ & $0.91 * * *$ & 1 \\
\hline 11. & Education2 & $1.08 * * *$ & $0.53 * * *$ & 6 \\
\hline 12. & Health and Social Work2 & $1.12 * * *$ & 0.39 & - \\
\hline 13. & Community, Social and Personal activities & $1.95^{* * *}$ & $0.61 * *$ & 5 \\
\hline
\end{tabular}

Notes: (i) OLS: ordinary least squares; RCM: random coefficient models.

(ii) Standard errors are in parenthesis.

(iii) ***,**and * indicate significance levels at $1 \%, 5 \%$ and $10 \%$, respectively.

${ }^{1}$ Including public education and health.

${ }^{2}$ Private sector.

Figure 11 - Revealed Comparative Advantage index for selected MENA countries.

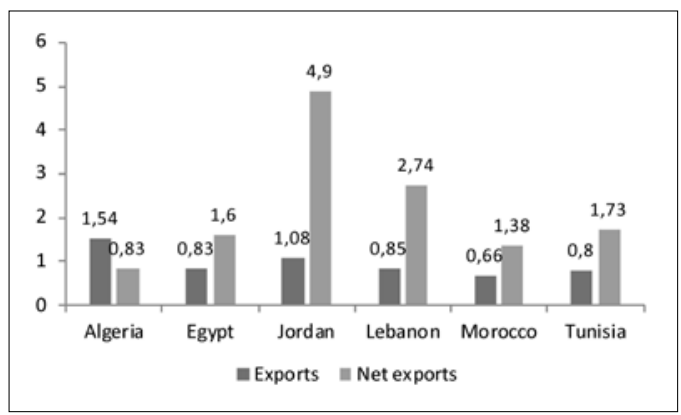

Source: Authors' own elaboration using the International Trade Center dataset.

Notes: Exports shows the RCA calculated using exports data and net exports using the net exports data.

\section{Conclusion}

The purpose of this article is to assess the relationship between the employment intensity and sectoral output growth, in order to examine whether economic was jobless or has created
Figure 12 - Number of commitments by country.

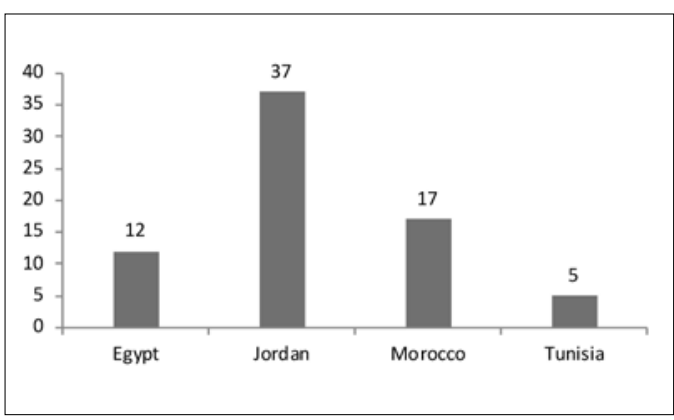

Source: Authors'own elaboration using the WTO online dataset.

more jobs. Using panel data for 10 sectors over the period 1983-2010 for two Middle Eastern countries; Egypt and Jordan, we estimate employment-value added elasticities at the sectoral level using a random coefficient estimation technique. Our main findings show that while man- 
Table 4 - Decomposition of output growth by sector in Egypt.

\begin{tabular}{|ll|c|c|c|}
\hline & $\begin{array}{c}\text { Average } \\
\text { employment } \\
\text { growth }\end{array}$ & $\begin{array}{c}\text { Average } \\
\text { value-added } \\
\text { growth }\end{array}$ & $\begin{array}{c}\text { Average labor } \\
\text { productivity } \\
\text { growth }\end{array}$ \\
\hline 1 & Agriculture, forestry \& fishing & $1.17 \%$ & $2.90 \%$ & $1.73 \%$ \\
2 & Mining & $6.96 \%$ & $10.42 \%$ & $3.46 \%$ \\
3 & Manufacturing Industries & $3.72 \%$ & $5.52 \%$ & $1.80 \%$ \\
4 Electricity & $3.52 \%$ & $8.13 \%$ & $4.61 \%$ \\
5 & Construction \& Building & $5.39 \%$ & $3.73 \%$ & $-1.66 \%$ \\
6 & Transportation, Storage, Com. and Inf. & $3.87 \%$ & $5.02 \%$ & $1.15 \%$ \\
7 & Suez Canal & $-0.23 \%$ & $8.07 \%$ & $8.30 \%$ \\
8 & Restaurants \& Hotels & $4.23 \%$ & $14.40 \%$ & $10.17 \%$ \\
9 & Real Estate Activities & $7.89 \%$ & $4.71 \%$ & $-3.18 \%$ \\
10 & Other & $2.79 \%$ & $4.04 \%$ & $1.25 \%$ \\
\hline
\end{tabular}

Source: Authors'own elaboration.

Table 5 - Decomposition of output growth by sector in Jordan.

\begin{tabular}{|c|c|c|c|c|}
\hline & Sectors & $\begin{array}{l}\text { Average } \\
\text { employment } \\
\text { growth }\end{array}$ & $\begin{array}{c}\text { Average } \\
\text { value added } \\
\text { growth }\end{array}$ & $\begin{array}{c}\text { Average } \\
\text { productivity } \\
\text { growth }\end{array}$ \\
\hline 1 & Mining and Quarrying & $1.0 \%$ & $3.7 \%$ & $2.7 \%$ \\
\hline 2 & Manufacturing & $6.8 \%$ & $6.7 \%$ & $-0.2 \%$ \\
\hline 3 & Electricity and Water Supply & $1.0 \%$ & $5.7 \%$ & $4.7 \%$ \\
\hline 4 & Construction & $10.0 \%$ & $4.7 \%$ & $-5.2 \%$ \\
\hline 5 & $\begin{array}{l}\text { Wholesale and Retail Trade, Repair of } \\
\text { Motor vehicles }\end{array}$ & $24.3 \%$ & $5.4 \%$ & $-18.9 \%$ \\
\hline 6 & Hotels and Restaurants & $11.0 \%$ & $3.7 \%$ & $-7.3 \%$ \\
\hline 7 & Transport, Storage and Communications & $2.5 \%$ & $5.5 \%$ & $3.1 \%$ \\
\hline 8 & Financial Intermediation & $4.5 \%$ & $11.2 \%$ & $6.7 \%$ \\
\hline 9 & Real Estate, Renting and Business Activities & $13.1 \%$ & $3.6 \%$ & $-9.4 \%$ \\
\hline 10 & $\begin{array}{l}\text { Public Administration, Defense, and social } \\
\text { security }\end{array}$ & $3.7 \%$ & $3.4 \%$ & $-0.3 \%$ \\
\hline 11 & Education (private sector) & $7.2 \%$ & $6.9 \%$ & $-0.2 \%$ \\
\hline 12 & Health and Social Work (private sector) & $9.9 \%$ & $7.4 \%$ & $-2.5 \%$ \\
\hline 13 & $\begin{array}{l}\text { Community, Social and Personal activities } \\
\text { and Service Activities }\end{array}$ & $12.4 \%$ & $4.4 \%$ & $-8.0 \%$ \\
\hline
\end{tabular}

Source: Authors'own elaboration.

ufacturing is the most important sector that creates jobs in Egypt, services are more important in Jordan. A more detailed look at the decomposition analysis shows that the contribution of employment growth to value-added was higher than that of labor productivity. As per Jordan, employment growth was sustained in trade, hotel and restaurant, real estates, construction, and 
other services. While labor productivity growth was in general lagging, the sector with the highest labor productivity growth was financial intermediation: this sector registered a steady increase in its contribution to GDP growth not backed up by an increase in employment. Further, despite privatization and public administration reform, the public sector in Jordan remains one of the most employment intensive sector.

From a policy standpoint, this paper shows that MENA countries are currently facing two main problems: first, employment growth is still modest; second, labor productivity is also low. Hence, we identify two sets of policies that should be put in place. On the one hand, in order to increase employment, more efforts are needed to promote investments in high-value added manufacturing sectors. Second, to increase investments that are labor intensive, incentives are an important determinant of the industrial sector performance. Incentives should be performance-based and enforced along with constant independent evaluation (El-Haddad, 2016). On the other hand, in order to increase labor productivity, MENA countries are in a dire need to improve the matching between the education system and the labor market requirements and hence to provide a more skilled labor force.

\section{References}

Abdul-Khaliq S., Soufan T., Shihab R., 2013. Intensive Economic Growth in Jordan during 19782010. International Journal of Business and Management, 8(12): 143.

Adachi H., 2007. Economic Growth and Unemployment: Theoretical Foundations of Okun's Law, The University of Marketing and Distribution Science.

Aghion P., Howitt P., 1994. Growth and Unemployment. The Review of Economic Studies, 61(3): 477494.

Alshyab N., 2012. Rent, Rentierism, and the Challenges of Economic Reforms: the Case of Jordan. Aachen: Shaker.

Alshyab N., Sandri S., Abu-Lila Z., 2018. Skills mismatch and returns to education in Jordan. EMNES Working Paper no. 12, April 2018 (www.emnes. org).

Amerah M., Khasawneh M., 1993. Unemployment in Jordan: dimensions and prospects. Center for inter- national studies, Royal Scientific Society, Amman, pp. 1-56.

Dumitrescu B.A., Dedu V., Enciu A., 2009. The correlation between unemployment and real GDP growth. A study case on Romania. Annals of Faculty of Economics, University of Oradea, Faculty of Economics, 2(1): 317-322.

Arico F., 2003. Growth and unemployment: towards a theoretical integration. Journal of Economic Surveys, 17(3): 419-455.

Bolbol A., Fatheldina A., Omran M., 2005. Financial development, structure, and economic growth: the case of Egypt: 1974-2002. Research in International Business and Finance, 19(1): 171-194.

Central Bank of Jordan, 1991. Twenty Eights Annual Report. Department of Research and Studies.

De Gobbi M., Nesporova A., 2005. Towards a new balance between labor market flexibility and employment security for Egypt. International Labor Organization, Employment Strategy Paper 2005/10.

Dobronogov A., Iqbal F., 2005. Economic Growth in Egypt: Constraints and Determinants. The World Bank, MENA Working paper no. 42.

El-Ehwany N., Metwally M., 2001. Labor Market Competitiveness and Flexibility in Egypt. ERF (Economic Research Forum) Working Paper no. 129.

El-Haddad A., 2016. Government Intervention with no Structural Transformation: The Challenges of Egyptian Industrial Policy in Comparative Perspective. ERF (Economic Research Forum) Working Paper no. 1038.

Fadel M., 2011. Public Corruption and the Egyptian Revolution of January 25: Can Emerging International Anti-Corruption Norms Assist Egypt Recover Misappropriated Public Funds?, Harvard International Law Journal, 52: 292-296.

Freeman D.G., 2001. Panel tests of Okun's law for ten industrial countries. Economic Inquiry, 39(4): 511-523.

Guirguis M., 2011. Sectoral Mobility and Egyptian Labor Reform. Stanford University, Department of Economics.

Goaied M., Sassi S., 2015. Trade liberalization and employment intensity of sectoral output growth: Lessons from Tunisia. The Economic and Labour Relations Review, 26(2): 261-275.

Hassan M., Kandil M., 2011. The Relation between Public and Private Employment in Egypt: Evidence and Implications. ECES (The Egyptian Center for Economic Studies) Working Paper no. 161.

Hassan M., Sassanpour C., 2008. Labor Market Pressures in Egypt: Why is the Unemployment Rate 
Stubbornly High?. Paper presented at the International Conference on the Unemployment Crisis in the Arab Countries, Cairo, Egypt, 17-18 March.

ILO (International Labor Organization), 2006. Termination of employment legislation digest. Egypt country profile.

Impiglia A., Lewis P., 2019. Combatting food insecurity and rural poverty through enhancing smallscale family farming in the Near East and North Africa. New Medit, 18(1): 109-112.

International Monetary Fund, 2004. Jordan: Selected Issues and Statistical Appendix, IMF Country Report no. 04/121.

Lacey M., Abdel Aziz S., 2015. Unresolved Issues in Egyptian Labor Law. Global Employment Lawyer, 1(2): 2-4 (Dentons.com).

Levine L., 2012. Economic growth and the unemployment rate. Washington, D.C.: Congressional Research Service.

Liu H., Zeng J., 2008. Determinants of Long-Run Unemployment. Southern Economic Journal, 74(3): 775-793.

Nassar H., 2011. Growth, Employment Policies and Economic Linkages: Egypt. Employment Working Paper no. 85. Geneva: International Labor Organization.

Neto A., Silva S.T., 2013. Growth and Unemployment: A bibliometric analysis on mechanisms and methods. FEP Work Pap, 498: 1-29.
Podgórska J., Leśniowska-Gontarz M., 2016. Analysis of the Relationship between Unemployment and GDP in Poland and Spain in the Years 2002-2015. Barometr Regionalny, 14(3): 59-67.

Radwan S., 1997. Towards Full Employment: Egypt into the 21st Century. ECES (The Egyptian Center for Economic Studies), Lecture series no. 10.

Salvatore D., 2018. Mediterranean challenge: Inclusive growth and sustainable development. New Medit, 17(3): 3-8.

Sharkawy, Sarhan, 2017. Egypt chapter. In: A guide to employment law across the MENA region. Glasgow: Clyde \& Co LLP.

Taghdisi-Rad S., 2012. Macroeconomic policies and employment in Jordan: Tackling the paradox of job-poor growth. Employment Working Paper no. 118. Geneva: International Labor Organization.

United Nations (UN), 2014. UN Expert Urges Longterm, Rights-based Approach to Water Crisis in Jordan. Available at: http://www.un.org/apps/news/ story.asp?NewsID $=47364$ \#TEhgiHtmkp

US Department of State, 2014. Investment Climate Statements.

World Bank, 2014. Arab Republic of Egypt - More jobs, better jobs: a priority for Egypt. Available at: http://documents.worldbank.org/curated/ en/926831468247461895/pdf/884470EG0repla00Box385343B00PUBLIC0.pdf. 